NEW LITERARIA-

An International Journal of Interdisciplinary Studies in Humanities

Volume 3, No. 1, January-February, 2022, PP. 128-133

ISSN: 2582-7375

DOI: https://dx.doi.org/10.48189/nl.2022.v03i1.014

www.newliteraria.com

\title{
Mundari Culture and Festivals: An Ecosophical Study of Ramdayal Munda's Adi- Dharam
}

\section{Hare Krishna Kuiry}

\begin{abstract}
'Jharkhand' word comprises of two words, jhar and khand. Jhar means bush or forest and khand denotes some part of earth or land. Then Jharkhand means the land of forest. This eastern state of India is famous for its natural resources and natural beauties. This treasure is protected by the Adivasi or tribal people of Jharkhand. Adivasi means the earliest or the first inhabitant of the land. It can be said that Adivasi and Nature are not separate entities. They are a complement to each other. Their culture, tradition, food, festival, and language are age-old, rich, and closely connected with nature. There are thirty-two tribal groups in Jharkhand and Munda tribe is one of the major tribal communities in Jharkhand.

Adi-Dharam is a book written by Ram Dayal Munda who was an anthropologist, folklorist, linguist, and academician. He was awarded Padmashri in 2010 for his immense contribution to Art in Jharkhand. This book Adi-Dharam is documentation of the religious beliefs of Adivasi of India especially in the Munda tribal community of Jharkhand, published in 2000. Through this book, Ram Dayal Munda tried to make a collection of festivals rituals, narratives, and prayers of Sarhul, Karma, and Sohorai festivals. This paper would deal with Ram Dayal Munda's keen observations of festival prayers, rituals, and festival narratives. This paper would also reflect on questions like how does the tribal culture connect with Mother Nature? It would also examine the ecosophical aspects of the Sarhul, Karma, and Sohorai festivals of adi dharam or ancient religion of the Munda tribe.
\end{abstract}

Keywords: Festival, Culture, Nature, Ecosophy, Adi-Dharam, Ram Dayal Munda.

\section{Introduction}

The wide arena of tribal culture creates a strong relationship among nature, tribal people, tribal language, food, tradition, and tribal festivals. Jharkhand is one such state which is not only rich in minerals but also rich in its culture. Here tribal communities play an important role in maintaining that cultural diversity. It can be said that tribal people who are one of the major leaders of Jharkhand movements are also responsible for the survival of the forest and forest ecosystem of Jharkhand. Their sensibility towards nature is reflected through their culture and festivals. Munda tribe's culture and rituals are surrounded with nature worship and that remains the same with other thirty-two tribal communities in Jharkhand.

Dr. Ram Dayal Munda who belongs to this Munda tribe was a pioneer among tribal people of Jharkhand. He was born on $23^{\text {rd }}$ August 1939 at Diuri village of Ranchi District in Bihar. Presently, it is in Jharkhand. He completed his Ph.D. degree in linguistics from the University of Chicago, the USA in 1970 and joined as Pro-Vice-Chancellor of Ranchi University and was in the post from 1985-1986. Later, he served as the Vice-Chancellor from 1986-1988 at the same university. He was awarded Sangeet Natak Academy Award in 2007 
and Padmashree Award in 2010 for his immense contribution to Art of Jharkhand (Manki, 2021, p. 55). Dr. Munda was an educationist, linguist, writer, musician, tribal activist, and visionary personality in the creation of the Jharkhand state. He had a plethora of publications and the Adi-Dharam book is one of those publications which was first published in 2000.

\section{Adi-Dharam}

Adi-Dharam is a Hindi word. Adi means ancient and Dharam means religion. Dr. Ramdayal Munda might have chosen this title because tribal practice and culture are part of the oldest belief system which is still alive through their rituals and festivals. The subtitle of the book is 'Religious beliefs of the Adivasis of India'. As an anthropologist he had researched and written about his own culture which most of the part was in oral form. Dr. Munda worked on an anthropological level, next on a social level and at last, he worked on an understanding level. In this book, he documented three major festivals of the Munda community which are- Sarhul, Karma, and Sohrai. He had written in detail about the rituals and khatas (festival narratives) of these festivals. He has also mentioned other events of the Munda community like marriage and death rituals. As he himself belonged to the same community he understood the social activities and their importance. He simplified and explained all the rituals through his writings so that readers could easily understand the importance of these pious activities of the tribal culture.

Samar Bosu Mullick who is also known as Sanjay Bosu Mullick is a tribal activist, writer, and lecturer- has written the preface of the book Adi-Dharam. He has commented a remarkable note about this book:

"The objective of the book is obviously to forge a unity of all the Adivasis who still follow the traditional faith at its different levels of disintegration by standardizing the basic tenet of the faith."

The author tried to unite all Adivasis through their culture, art, and music that shows the world an alternative way of living with nature and this book, Adi-Dharam is one of the many initiatives through which he tried to protect both tribal and nature.

\section{Mundari Festivals}

There are many types of festivals and those have different purposes also, like hunting festival, religious festival, war festival, and so on but most of the festivals of tribal people follow seasons and the agricultural cycle. Sarhul, Karma, and Sohrai are the major festivals of the Munda community and these follow the seasonal and agricultural cycle. Broadly, agriculture has a larger sense but here it focuses mainly on paddy cultivation because rice is the primary food of Jharkhand. According to the changes of seasons, Munda community celebrates these festivals and expresses their gratitude towards nature for offering a bountiful crop. Here festivals are celebrated in four parts, first 'fasting', the second 'offerings', third 'song and dance, eating and drinking', and at last 'winding up'. Planning and discussion of any festival starts at Akhra and the festival ends also at Akhra.

\section{Sarhul Festival}

Sarhul festival is also called jangkor, Khaddi, Baha, or ba which is a grand festival of Jharkhand, celebrated by Munda, Oraon, Santhal, Ho, and other tribal communities of Jharkhand. Sal flower is the centre of the Sarhul festival. 


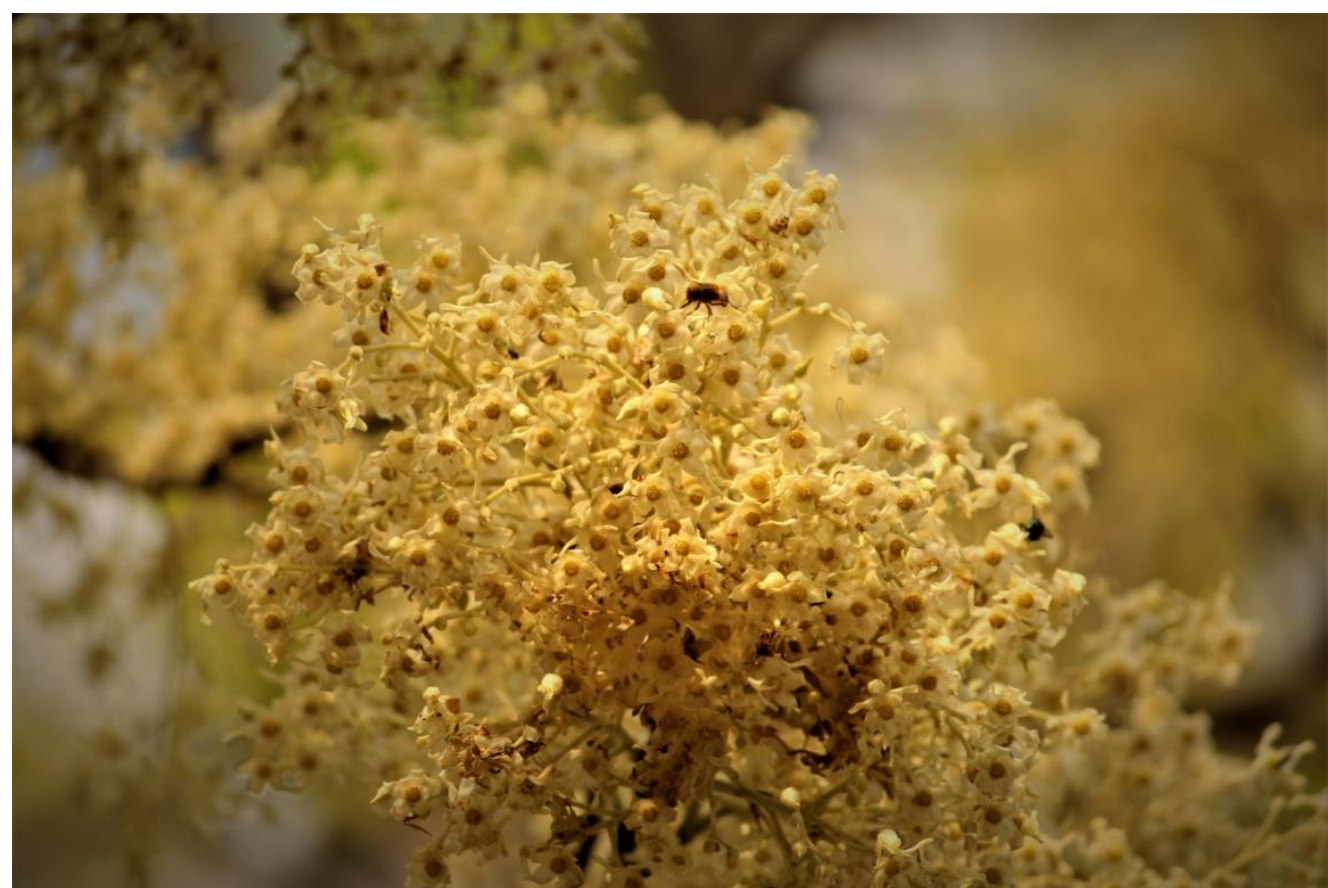

Fig. 1. Kuiry, Hare Krishna. Sal flower. Sarhul, Brambe, Ranchi, Jharkhand. 13 April 2021.

In welcoming the sal flower tribal people celebrate the spring festival. It is observed on Chaitra Shukla Tritiya, the third day after the new moon in Chaitra, the twelfth or last month of the Bengali solar calendar, and the first month of the Hindi solar calendar. Sarhul is a fourday festival. The first day is the day of "the fish and the crab", who are the ancestor of the earth. Tribal people catch them with respect and include them in the evening meals. The next day all gather with their hunting weapons, musical instruments, and collect ingredients for Tehri at Sarnasthal. Pahan worships the Great Spirit and sacrifices chickens and offers it to the Great Spirit or Singbonga, Adi Maa, and the Water Spirits. Later they pray and prepare Tehri and distribute it among all. Meanwhile, Pahan forecasts the rainfall of the upcoming seasons. On day three they go for the procession and last day they celebrate the Phulkhonsi ritual. Pahan goes to every house of the village and tugs the sprig of the sal flower. With this ritual, everyone greets johar, hugs each other with warm brotherhood, and takes blessings from elders and ancestors. Thus, Sarhul takes a form of festive mood.

\section{Karam Festival}

Karam is also a harvest festival of Jharkhand. Karam tree is the centre of this festival. This festival is held on the eleventh day of Bhado, the fifth month of the Bengali calendar. This festival is celebrated not only among the Munda community of Jharkhand but also among the Kurmali, Santhal, Kharia, etc. in Jharkhand, Bihar, Orissa, Chattisgarh, West Bengal. It is a three-day festival. Seven or five days before Karam Puja, sisters bring clean sand from the river in a basket and sow seven types of grains in it. These grains are barley, wheat, corn, urad (black gram), kurthi (horse gram), black chickpeas, and peas. On the day of worship, the Karam tree is planted in the courtyard of the house or Akhra. Devotees come with their jawa. Pahan performs the worship of the Karam raja with the kathas of two brothers- Karma and Dharma. Karam dance is performed on the ground. The next day Karam tree is immersed in the river or pond. Jawa is distributed as Prasad of blessing and offerings.

\section{Sohrai Festival}

Sohrai is a cattle festival. It is held on the new moon day of Kartik, the tenth month of the 
Bengali calendar in honor of the cattle because they assist the whole process of agriculture, especially in paddy cultivation. It is a two-day festival. One week before Dipavali songs are sung in honor of the cattle. On the first day of the day of Dipavali, a lamp is kept lit for the whole night at the cattle shed. The next day in the morning, the entrance of the cattle shed is cleaned and decorated with the design of gunri or rice paste. Then cattle are bathed and brought home stepping on a beautifully designed path. After that cattles are worshiped and given fresh grass. Dishes like pua and pitha are made at home and those are offered as a prasad and distributed among neighbors.

\section{Mundari Culture, Festivals, and Ecosophy}

The blended word, Ecosophy is formed with two words, ecology and philosophy. It interconnects the concepts of environment and social aspects. The Norwegian father of Deep Ecology, Arne Næss, and French post-Marxist philosopher and psychoanalyst Félix Guattari have given the idea of ecosophy. Naess aimed to transform society's ecological perspective. He has written a book, "Ecology, Community, and Lifestyle: Outline of an Ecosophy" in 1989.; His work influenced the Greenpeace founders. Essays by Naess, Chellis Glendinning, Gary Snyder, Dolores LaChapelle, Paul Shepard, and others are included in this book.

Culture, festival, ritual, and tradition help a community to live with their own identity, and the Munda community's culture and festival ritual respect Mother Nature and preserve it. Dr. Munda's philosophy primarily focuses on the environment of Jharkhand and its tribal population. Throughout his life, he tried to protect the culture of the tribal people and unite all tribes through the celebration of festivals so that nature never gets separated from their lives. Samar Bosu Mullick, in the preface of Adi-Dharam, mentions "The Adivasi are going to play a historical role in presenting an alternative way of life and belief that is capable of protecting the planet and the people from the impending threat of anthropogenic disaster." The comment of the book of Dr. Ramdayal Munda's Adi-Dharam, religious beliefs of the Adivasis of India emphasizes the importance of preservation of tribal culture of Jharkhand.

Justin B Richland, an associate professor of Anthropology at the University of Chicago has written that "Culture is often described as social rather than individual, local rather than universal, learned rather than instinctive, historical rather than biological, evolved rather than planned, distributed rather than centralized, and cultivated rather than coarse."(Richland, 2018). Therefore, all the festivals, rituals, worshiping, socialize practices come under the umbrella term "Culture". Tribal culture has a huge significance on nature and the ecosophical concept of Dr. Ramdayal Munda. Dr Munda said that "The Adivasis' long association with forest has deeply affected him psychologically. Searching for peace, the last goal, the Adivasi always moves towards the forest..." Nature and adivasi are complement to each other and all these rituals and festivals are the celebration of the relationship of the creator and creation. The celebration of the relationship can also be found in the importance of Sarhul, Karam, and Sohrai, the three major festivals of the Munda community of Jharkhand.

Sarhul is a nagpuri word. It is formed of two words Sarai and Hul. Sarai is Sal and hul mean "collectively", and also "grove". This sal flower is representative of all flowers in the Munda community. Through this festival pahan welcomes nature in that hope of good agricultural production and no Adivasi would bring home any new leaves or flowers or use them in any way before the pahan has formally welcomed it. All the natural elements take an important role during the Sarhul festival because there are many spirits like the Great Spirit, Water Spirit, Hill Spirits, and all they are in the position of God in the Munda community. The fish, the crab, the turtle, and the earthworm- all these little creatures take a big space in the culture of the Mundas because they are not the ancestors. They helped singbonga in the creation of the earth.

Let's take a close look at the mantra of the Sarhul festival. Adivasi people's world is made of their nature, their ancestors, and their gods. These lines of mantras show the close 
relationship between the creator and the creation.

Oh Great Spirit of high heavens.

Mother Earth down below.

You rise like milk,

you set like curd...

...We invite you, we call upon you.

You sit with us, you talk with us.

A cup of rice beer,

a plate of mixed gruel.

You drink with us, you eat with us. (Munda, 2000, p.14)

The lines of the prayer are chanted by the pahan at sarnasthal and this is applicable to most occasions with slight differences. As the earth is the primary container of the religion of Adivasi people and their identity therefore earth is greeted in all mantras of worship.

Sarnasthal or jaher is a small grove. This place has immense significance in all festivals of the tribal of Jharkhand. It is believed that Sarna Maa lives in this religious grove. As it is a religious grove so it is strictly prohibited to cut trees from there and hence it creates a small forest eco-system.

Karam festival is directly concerned with cultivation: involving sowing, sprouting, and growth of crops. Karam the word also denotes work or hard work. This festival is celebrated during the leisure period after the hard work of the plantation process of paddy. Karam tree is the core of the festival and on the last day of the Karam festival, sal or bhelua branches are planted amidst the crop field with the hope that the Karam raja will protect their crops. One observation that can also be noticed at that point is that the drongo bird usually sits on the branch of sal and eats unwanted insects from the paddy field.

Sohrai festival is one such festival that redefines the definition of the family. It shows the true bond of a relationship. "Family are usually the people we care about most, and the ones we are most likely to protect from harm. And being a member of a family (a mother, father, uncle, or sister) is often one of the strongest identities people have. In The Land of the Spotted Eagle, Standing Bear uses these lines are talking about America the explicit term 'kinship' to place humans within a family that includes other living beings who are not human: 'kinship with other orders of life' 'kinship to other lives'" (Bear, 2021, p. 202).

Sohrai festival is observed in honor of the cattle and it is also an agriculture-centered festival. As the cattle assist through the whole process of paddy cultivation and other agricultural activities so it is the best time to care for them, worship them, and dedicate these days of the festival.

"... if all living things are siblings, then we must love, revere, and protect them" (Stibbe, 2020, p. 422).

Tribal people believe in interdependence rather than independence. Every natural object and living creature get respect in tribal culture. Sohrai festival is the celebration of co-existence and celebration of the relationship of the man and cattle.

\section{Conclusion:}

"The Adivasi are going to play a historical role in presenting an alternative way of life and belief that is capable of protecting the planet and the people from the impending threat of anthropogenic disaster." These lines are commented by Samar Bosu Mullick in the preface of Adi-Dharam. Mundari culture and festival rituals show gratitude to Mother Nature and tribal people are more concern about their surroundings and nature therefore this culture shows the world the alternative way of life. Being a visionary person, Dr. Ramdayal Munda can analyze the cultural importance of tribal people and his own community. He also believed that tribals would survive only if their culture continued to flourish. It gives an identity and rhythm to their 
life. Mundari culture and festivals always enrich the process of enculturation from where people can learn the value and importance of their surroundings. Dr. Munda's philosophy is projected through the explanations of the importance of these cultures and festivals of the Munda community and it shows the close bonding of nature, humans, and society. There is no hell and no heaven where the spirit may go after death. Munda people believe that their spirits go to their ancestors after death therefore Munda and other tribal people of Jharkhand always try to make the earth a better place for them and their ancestors.

\section{Reference}

Bear, C. S. (2021). Land of the Spotted Eagle - American Indians. Houghton Mifflin Company. Hoffmann, J., \& Emelen, A. van. (1950). Encyclopaedia mundarica. Supt., Govt. Print.

Manki, B. R. D. M. A. R. S. (2021). Arandi Bonga. RUMBUL.

Muṇ̦ā, R.(2000). Adi-dharam, Religious Beliefs of the Adivasis of India.( 1st ed.) Sarini.

Richland, J. B. (2018, February 8). Tribal Culture and Economic Growth. PERC. https://www.perc.org/2013/12/04/tribal-culture-and-economic-growth/

Stibbe, Arran. (2020). Toward a grammar of ecocultural Identity. In Milstein, T., \& CastroSotomayor, J. (Ed.), Routledge Handbook of Ecocultural Identity (pp. 416-430). (1st ed.). Routledge.

\section{$\underline{\text { Bio-note }}$}

Mr. Hare Krishna Kuiry is an independent researcher. He has completed his master degree in English Studies in 2020 from Central University of Jharkhand, Ranchi, India. His area of interest is tribal Issues, culture and festivals. His topic of the dissertation is "Tribal Festival Celebrating Nature in Jharkhand: An Eco-Critical Study of the Rituals and Lok kathas of Tussu and Sarhul". He has also presented paper "Life of Adivasis during Pandemic" at e-Co Exist 2020, two-day international conference on Coping with Covid-19: Sustainable Living in the Era of Pandemic, organized by IQAC, Belda College. Research article, "Death to Deification: Reading the Many Tales of Goddess Tusu" in Journal of the Department of English, Vidyasagar University, Midnapore, Vol 14 written by Bhattacharji, Shreya and Hare Krishna Kuiry. He has also presented documentary on Murma Mela at Birsa Munda Language and Cultural Festival 2020.

Email Id: hare.krishnajhalda@gmail.com 